\title{
Low Carbon Concept of Sruni Village through The System of Renewable Energy
}

\author{
Erni Setyowati ${ }^{1}$, Nashrullah Dahlan Lubis ${ }^{2}$, Subrata Aditama Kittie Aidon Uda ${ }^{3}$, Agitta Raras \\ Putri $^{4}$ \\ ${ }^{1}$ Magister Program of Architecture,Engineering Faculty, Diponegoro University, Semarang, Indonesia \\ ${ }^{2}$ Undegraduate Program of Architecture, Engineering Faculty, Diponegoro University, Semarang, Indonesia \\ ${ }^{3}$ Civil Engineering, Engineering Faculty, Diponegoro University, Semarang, Indonesia \\ ${ }^{4}$ Urban and Regional Planning Department, Engineering Faculty, Sultan Agung University, Semarang, Indonesia
}

Corresponding e-mail: ernisyahdu@gmail.com

Article info:

Received : 28-06-2018; Accepted : 30-06-2018

\begin{abstract}
Indonesia is the fourth most populous country in the world. The highest population density exists in urban areas and gradually becomes lower in periphery or rural. Therefore the city in Indonesia often looks slum because of over density. The village is the smallest part of a city. In crowded cities there are often slum villages. This paper highlights a model of slum villages in Wonosobo, Sruni village, and solutions to transform socio-cultural communities through renewable energy design based on low carbon concept. The method used is quantitative method based on demographic data of Sruni village, Wonosobo. Based on data and analysis, it is found that renewable energy that can be applied in Sruni village are sanitation, drainage and water waste management, solid waste, rain water harvesting, water wheel and solar panel energy. At the end of the discussion, it is concluded that there are needs to be re-densification or verticalization of the house, in order to obtain more public green open spaces. Meanwhile, based on quantitative analysis, Sruni village needs rain water harvesting system, additional 1 unit of communal Sewage Treatment Plant (STP) serving 80-100 households gray and black water, and 1 units of water wheels to accomodate electricity need of four inhabitant RTs in Sruni village .
\end{abstract}

Keywords: slum village, renewable energy system, low carbon concepts

\section{Introduction}

As improving slum village become one of the intensive program issued by the Ministry of public work and housing of Indonesian government, the Wonosobo district is appointed to be a Low carbon eco district model. The district is located between two active volcano, Sumbing mount and Sindoro mount, in the centre part of Central Java Province. One of many villages in Wonosobo district selected as an eco-village model is kampung Sruni, a village close to the alun-alun, a centre green open space in Wonosobo district located near the municipality offices.

The kampung Sruni is a village with a strong socio-cultural aspect and has been declared as a tourism destination village through the Spatial Planning Regulation of Wonosobo regency government. Eventhough Sruni village has favourable culture and specialities, the kampung is catagorized as slum village due to its high density population. In line with the Ministry of public work and housing program to prevent slum, the kampung has been choosen as a model of low carbon village and utilization of natural renewable energy. The natural resources that could be recycled as a renewable energy are a huge amount of heavy rain all over the year, urban farming, spring-rich beautiful Semagung river in the east part of kampung, mutual traditional cooperation among the inhabitants called 'gotong-royong', localtraditional arts such as music, traditional artistic housing considered as homestays, dance and painting art. 
Many studies discussed low carbon concepts and strategies, the first example is a study conducted by Shan and Li (2011). Shan and Li stated that the low carbon city concept can be approached by the integrated development of economy, community, population, environment and natural resources(Cao \& $\mathrm{Li}, 2011)$. They choosed a new Tianjin eco-city as a model of the low carbon city. In their paper, they continue argued that the the low carbon concept is appropriately to be applied in the Tianjin city because the city developed and opened to the industrial and commercial activities. Although they discussed a low carbon concept, they have not been calculated the natural resource managemennt and utilization in the city model. Like Shan and Li, Su, et.al also studied the low carbon concept for further development of cities(Su, Chen, Xing, Chen, \& Yang, 2012). Their paper also discussed how the low carbon construction could be implemented in the cities in China and how the appropriate way for the cities to be more sustainable.

A different study has been conducted by Sieting T, et.al (2015). They studied a framework of low carbon city improvement (LCCl) and gave a rank of ten cities in the world to observe their carbon emission level(Tan, Yang, \& Yan, 2015). The conclusion of the paper is that the low carbon level of cities in Europe is higher than that of the Asian and American cities because of more activities in European cities and the variables of environment and infrastructure in Asian and American cities are quite good. Several research which are rather similar with the Sietings study were conducted and delivered the problem and review of the low carbon viewpoints in several cities(Benger, 2014; Jiang, Chen, Xu, Dong, \& Kennedy, 2013; Ruan, Cao, Feng, \& Li, 2017; Xie, Gao, He, \& Feng, 2016).The low carbon concepts not only should be implemented to the big- high densely populated city like Tianjin, it also should be implemented in low density - medium city like Adelaide, Aiustralia. Simon, N.B (2014) observed the CO2 emission in a whole Adelaide city which has low responds regarding the concepts despite they have an abundant of natural resources and stable policies related to the sustainable environment(Benger, 2014). Refer to Simon that the carbon emission is influenced on how big is the household, the number of household, people activities and what kind of fuel they used for the daily activities. Although the discussion is very comprehensive, but the did not calculate the amount of renewable energy implemented in the city model.

The same opinion is upwarded for several studies that had not discussed the calculation of low carbon footprint and the renewable energy needs, althoug they discussed about the low carbon theories(Ge, Luo, \& Lu, 2017; Jenssen, König, \& Eltrop, 2014; Moriarty \& Wang, 2014; Mulugetta \& Urban, 2010; Xie et al., 2016).The research issuing the composting of organic waste of palm industries with the community participative approach has been done by Cassendra, et.al (2016)(Bong et al., 2017). The participation of the society in the crude palm oil plantation is the focus of the paper with an iteresting results stated in the paper that the green region development is supported by the daily activities of community that made fertilizer made of the palm plantation waste. The research studied by Moriarty and Wang (2014) argued that fossil fuel energy must be cutted down to reduce the Grenn house gas (GHG). By cutting down the energy used, the city could reduce the urban heat island effect and air pollution. They also proposed approaches consists of creating the alternative energy, energy conservation and energy efficiencies(Moriarty \& Wang, 2014). Several environmental problem regarding the low carbon concepts have been discused in several research(Mapes \& Wolch, 2011; Middlemiss \& Parrish, 2010; Smith, Clayden, \& Dunnett, 2009).

The studies discussed above are very interesting in the context of the low carbon theories, but they rarely highlighted the calculation of renewable energy on term of the implementation of low carbon concepts. Eventhough the Indonesian government has intensively conducted program of 'kota hijau', it means green city, but the implementation has not been successfuly and completely realized. This paper focuses on the calculation of renewable energy system to provide the inhabitant daily needs such as drinkable water, electricity, fertilizer and fuel. 


\section{Methods}

The low carbon concepts and the kampung Sruni conditions is analyzed by using descriptive methods. The focus of this paper is describing the potential aspects of the kampung on term of the sustainable resources and the socio-cultural variable which has a strong participative community behavior called 'gotong-royong', a traditional cooperation among the community to develop their village. The concepts and calculation of renewable energy system are analyzed by quantitative methods depend on many references and based on low carbon city point of view. The renewable energy system in kampung Sruni that could be implemented are sanitation and water management, waste management and energy.

\section{Discussion}

Located in centre of central Java Province, Indonesia, the Wonosobo city becomes a tourism destination because of its beautiful place, comfortable climate, geothermal energy resource of Dieng plateau, and favourable local art and culinary sector. The kampung Sruni is involved in the area of subdistrict Jaraksari. Refer to the Central Bureau of Statistics of Wonosobo, the sub district of Jaraksari is the most densely populated subdistrict in Wonosobo city with the density of 6396 inhabitans per square kilometre area.

The Wonosobo district is delimited Temanggung district in the north, by Banjarnegara district in the west, Kebumen district and Purworejo District in the south, Magelang district in the east. The topography is catagorized as highland with the height range between $275-2,250$ above sea level. The location of Wonosobo city and the pilot project of kampung Sruni are described in figure 1.

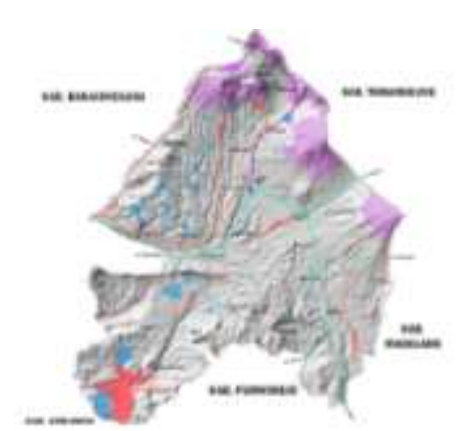

(a)

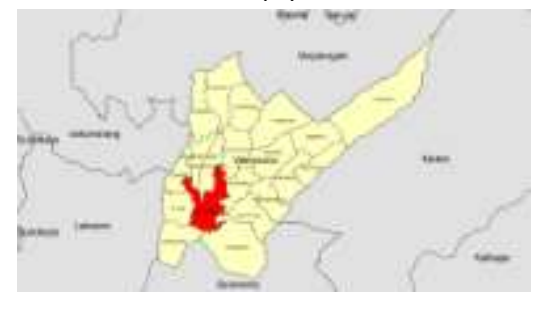

(b)

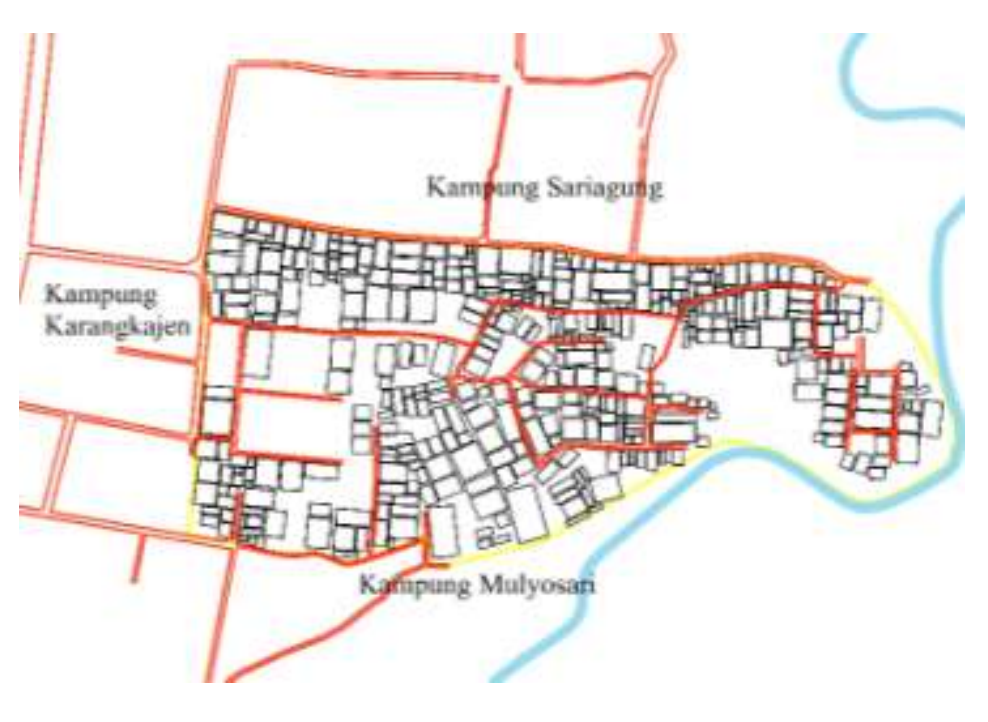

(c)

Figure 1. (a) Wonosobo District; (b). Wonosobo city; (c) map of kampung Sruni (Central Bureau of Statistics of Wonosobo Regency, 2017)

The climatologigal data are shown in figure 2.

In the process of observation, we held several focus group discussion with the inhabitant regarding any solutions that could be applied to the kampung. The results of the focus group discussion (FGD) is explained in the table below: 
Table 1. Kampung Sruni - an existing renewable energy and the result of FGD with the inhabitant:

\section{The component of The expectation of the inhabitant renewable energy

\begin{tabular}{|c|c|c|}
\hline $\begin{array}{l}\text { Sanitation } \\
\text { waste }\end{array}$ & and & $\begin{array}{l}\text { - Sruni village needs additional community based sanitation } \\
\text { accomodating } 80-90 \text { households solid waste. } \\
\text { - Inhabitants need better and additional drainages, which } \\
\text { several parts have no drains to flow the heavy rain. The heavy } \\
\text { rain falls almost every day in Wonosobo city. Refer to the } \\
\text { Central Bureau of Statistics of Wonosobo, the rain fall during } \\
283 \text { days per year. }\end{array}$ \\
\hline
\end{tabular} \\ Clean water and the Due to the high rain fall in Wonosobo city, it is important to harvest climate the heavy rain and recycle it to be clean water for the daily consumption. \\ Electricity energyof Semanggung River \\ Urban farming and cattle \\ Climate \\ Environment \\ - Kampung Sruni has three springs in surrounding the Semaggung river in the east side of the kampung. The springs are potential to be altered as electrical energy by water wheel energy. \\ - The electrical energy can be distributed to the whole part of the kampung to fulfill the the daily electricity need of the inhabitant. \\ - The urban farming in the south part contribute the huge amount of oxygen toward the atmosphere of the kampung. Although the farming area is not included in the administrative area of kampung Sruni, the drainage and sanitation flowed within the kampung can be directed to the farming area after the treatment process. \\ - Several cattles in the kampung are potential energy to be recycled as biomass energy that could be used an alternative energy excluded the fossil fuel. \\ - The temperatur is catagorized as an moderate comfortable with range of temperature between $21-28^{\circ} \mathrm{C}$ due to the mountainuous climate of Dieng plateau. \\ - The comfortable temperature and presipitation interacts the foreign tourist to stay a long in the Wonosobo city. \\ - Due to the very high rain fall along the year, the inhabitants desire to have the rain water harvesting to obtain the clean and drinkable water for the community of kampung Sruni. \\ The potential Semanggung river has not been utilized optimally related to its beautiful scenery for tourism and potential energy that could be altered as an electricity for energy need of the inhabitant.}

The potential of the renewable energy above can be seen in the figure 3 . The next data are the demography and climatology data.

Table 2. Demography data of the kampung Sruni

\begin{tabular}{|c|c|c|c|c|c|}
\hline & RT 05 & RT 07 & RT 08 & RT 13 & Total \\
\hline $\begin{array}{l}\text { Number } \\
\text { households }\end{array}$ & 22 & 31 & 38 & 39 & 130 \\
\hline $\begin{array}{ll}\begin{array}{l}\text { Number } \\
\text { inhabitants }\end{array} & \text { of } \\
\end{array}$ & 86 & 124 & 145 & 163 & 518 \\
\hline
\end{tabular}


The Wonosobo city is a small city, because the regency of Wonosobo is a huge area with the capital city of the regency is Wonosobo city. Due to its small area, so there are few inhabitants in the city. From the table 2, it is known that there is only 518 inhabitants live in kampung Sruni which has floor area of kampung at least $4 \mathrm{Ha}$. The Jaraksari sub district is the most densely populated sub-ditrict that impacted the kampung Sruni as its high density population of 12,634 inhabitants per square kilometre. This demography data will be base of the renewable energy calculation of the kampung.

Table 3Climatological data of the kampung Sruni

\begin{tabular}{lllllllllllll}
\hline $\begin{array}{l}\text { Temperatur } \\
\left({ }^{\circ} \mathrm{C}\right)\end{array}$ & Jan & Feb & March & April & May & June & July & August & Sept & Oct & Nov & Dec \\
\hline $\begin{array}{l}\text { Average } \\
\text { Minimum }\end{array}$ & 22.0 & 22.1 & 22.4 & 22.5 & 22.8 & 22.3 & 21.8 & 22.0 & 22.4 & 22.9 & 22.4 & 21.8 \\
Maximum & 26.0 & 18.0 & 18.2 & 18.3 & 18.5 & 17.5 & 16.7 & 16.7 & 17.3 & 18.1 & 18.1 & 17.7 \\
$\begin{array}{l}\text { Rainfall } \\
(\mathbf{m m})\end{array}$ & 513 & 443 & 486 & 339 & 254 & 136 & 110 & 93 & 118 & 237 & 357 & 486 \\
\hline
\end{tabular}

Refer to the central Bureau of Statistics, that the climate characteristic of Wonosobo city is catagorized as tropics but low in temperature comparing other cities due to the influence of highland Dieng plateau and its topography, low average yearly temperature of $22.3^{\circ} \mathrm{C}$, high presipitation (80-95\% Relative Humidity) and very high rain fall of $312.66 \mathrm{~mm}, 60-70 \%$ days along the year(BPS, 2017a, 2017b).

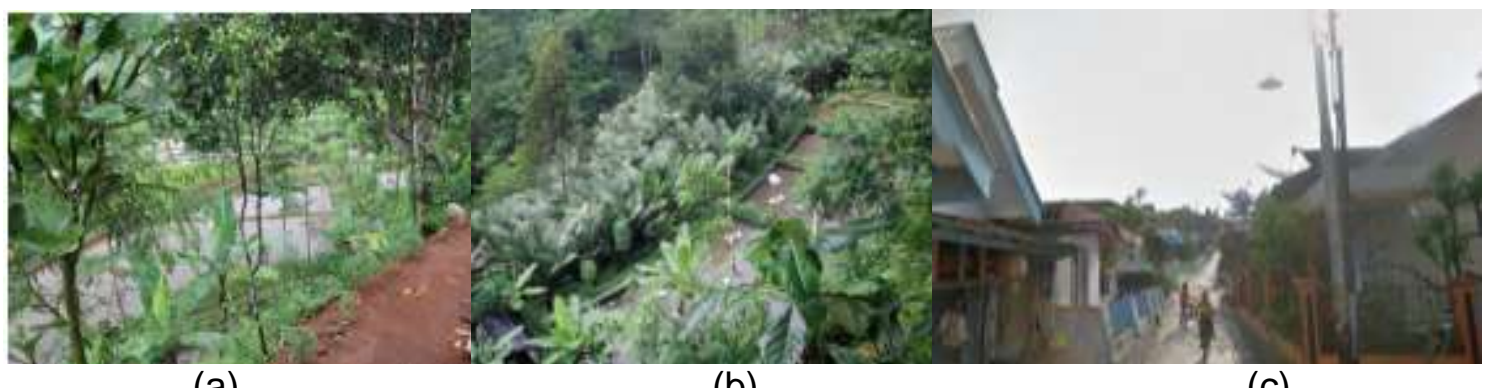

(a)

(b)

(c)

Figure 2. The Renewable energy of the kampung Sruni, (a). The urban farming in Sruni; (b) The spring of The Semanggung River; (c) the poor drainage and the very narrow street

\subsection{Sanitation and Waste water management}

The drainage system in kampung Sruni is designed to provide a better and more adequate dimension of drainage based on the low carbon concept. Accomodating 80-90 households solid waste consisting grey and black water in kampung Sruni, the community based sanitation should be made in the southern part of the kampung. The table below (table 4) depicts the water management system in kampung Sruni, Wonosobo city based on the demography data in table 2 :

Table 4. Total inhabitant water consumption in kampung Sruni

\begin{tabular}{ccccc}
\hline $\mathbf{R T}^{*}$ & Households & $\begin{array}{c}\text { Number of } \\
\text { inhabitants }\end{array}$ & $\begin{array}{c}\text { Water } \\
\text { consumption } \\
\text { (litres) }^{*}\end{array}$ & $\begin{array}{c}\text { Total } \\
\text { (litres/day) }\end{array}$ \\
\hline $\mathbf{0 5}$ & 22 & 86 & 120 & 10,320 \\
\hline $\mathbf{0 7}$ & 31 & 124 & 120 & 14,880 \\
$\mathbf{0 8}$ & 38 & 145 & 120 & 17,400 \\
\hline
\end{tabular}




\begin{tabular}{ccccc}
\hline $\mathbf{1 3}$ & 39 & 163 & 120 & 19,560 \\
\hline Total & 130 & 518 & & 62,160 \\
\hline
\end{tabular}

${ }^{*} \mathrm{RT}$ (Rukun Tetangga) is a group of household in Indonesian village consisting approximately $80-100$ houses

${ }^{* *}$ Low Carbon city (Jain,A.K, 2009)(Jain, 2009)

Based on the standard of National Indonesia (SNI 03-7065-2005) on Standardization of plumbing system(BSN, 2005). The calculation of the total daily water consumption for the inhabitants in kampung Sruni is described in the table 5.

Table 5. Water per day of inhabitants in Sruni village

\begin{tabular}{|c|c|c|c|c|}
\hline Alocation & Type of Activities & $\begin{array}{c}\text { Percentage } \\
(\%)\end{array}$ & $\begin{array}{l}\text { Water used } \\
\text { per day (litre) }\end{array}$ & $\begin{array}{l}\text { Quantity } \\
\text { (litre/day) }\end{array}$ \\
\hline \multirow[t]{6}{*}{ Grey water (GW) } & Bath room* & 20 & 62,160 & 12,432 \\
\hline & Washing clothes* & 12 & 62,160 & 7,459 \\
\hline & Washing dishes* & 13 & 62,160 & 8,081 \\
\hline & Washing hands* & 8 & 62,160 & 10,013 \\
\hline & e. Plants* & 6 & 62,160 & 4,973 \\
\hline & Sub Total & & & 42,958 \\
\hline Black water (BW) & Toilet & 35 & 62,160 & 21,756 \\
\hline $\begin{array}{l}\text { Drinkable water } \\
\text { (DW) }\end{array}$ & Drinkable water & 6 & 62,160 & 3,730 \\
\hline \multicolumn{4}{|c|}{ Total water management $=$ Sub total $+B W+D W$} & 25,486 \\
\hline
\end{tabular}

*Daily activities flushes grey water (Jain, A.K, 2009)

Nowadays, Indonesian villages have used clean water from the PDAM (Indonesian Clean water supply agency). In the future, due to the abundant amount of rainfall in Indonesia, the clean water could be harvested from the rain by 'Rain water harvesting system'.

The grey and black water flushed from the communities toilet should be collected in the community based sanitation or Sewage Treatment Plant (STP) accomodating the water waste comes from the toilets of 80-90 households and divided into two areas or groups, firstly is group of RT 05 and RT 08 and secondly is group of RT 7 and RT 13 in the eastern part of kampung. The calculation of grey and black water system are presented in table 6 .

Table 6. Water management system of kampung Sruni

\begin{tabular}{|c|c|c|c|c|}
\hline $\begin{array}{l}\text { Water } \\
\text { management }\end{array}$ & Equation & $\begin{array}{l}\text { Capacity } \\
\text { (litres/day) }\end{array}$ & $\begin{array}{l}\text { RT } 05 \text { and } 08 \\
\text { (litres/day) }\end{array}$ & $\begin{array}{l}\text { RT } 07 \text { and RT } \\
13 \text { (litres/day) }\end{array}$ \\
\hline Grey Water & $\begin{array}{l}\text { Grey water }-(2 \% x \\
\text { grey water }) \\
=42,958-1,476\end{array}$ & 42,099 & 18,774 & 23,325 \\
\hline Rain Water & $\begin{array}{l}=41,000^{*} \times 0,313^{\star *} \\
=12,833 \mathrm{~m} 3 / \text { month } \\
\text { Rain water }-(2 \% \times \\
\text { rain water }) \\
=427,766-8,555\end{array}$ & 419,211 & 186,945 & 232,266 \\
\hline \multicolumn{2}{|c|}{ Water Treatment Plant } & & 161,158 & 140,616 \\
\hline $\begin{array}{l}\text { Sewage } \\
\text { Treatment Plant } \\
\text { (Communal STP) }\end{array}$ & $\begin{array}{l}=\text { Toliet waste }-(2 \% \\
x \text { toilet waste }) \\
=21,756-435\end{array}$ & 21,321 & $\begin{array}{l}9,508 \\
\text { litres/day } \\
=10 \mathrm{~m} 3 \\
=2 \times 2,5 \times 2\end{array}$ & $\begin{array}{l}11,813 \\
\text { litres/day } \\
=12 \mathrm{~m} 3 \\
=2 \times 3 \times 2 \mathrm{~m} 3\end{array}$ \\
\hline
\end{tabular}




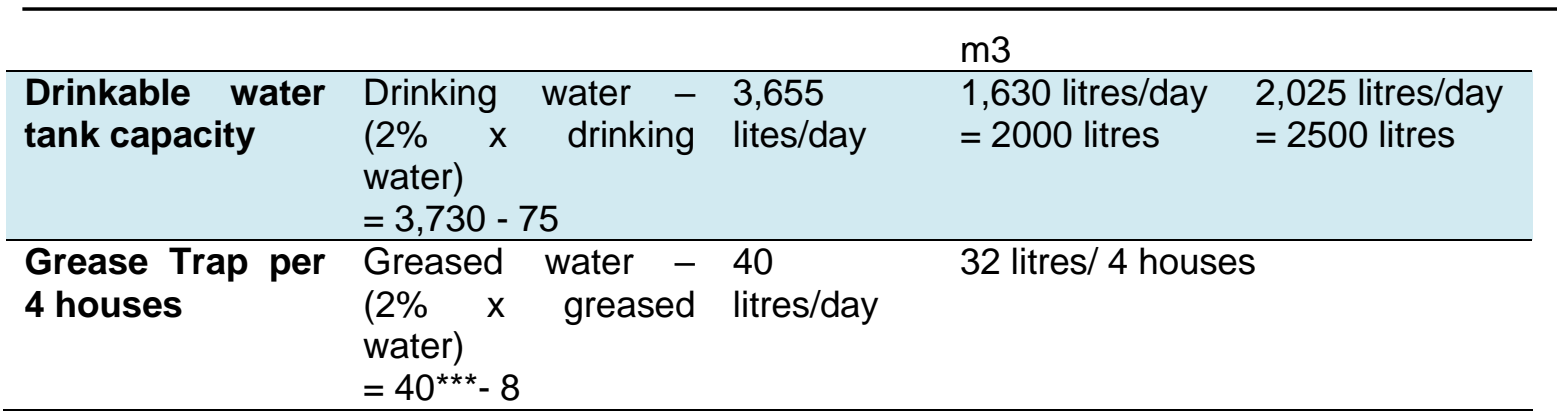

Area of kampung; ${ }^{*}$ Rainfall in Wonosobo in metre cubic $312.66 \mathrm{~mm}$ is equal to $0.313 \mathrm{~m}$ (Central Bureau of Statistics of the Wonosobo regency, The central Java Province, Indonesia)

${ }^{* * *}$ Volume of greased water comes from kitchen and washing dishes.

\subsection{Waste management}

The potential solid waste or black water waste in kampung Sruni comes from human all over the kampung and cattle in the southern part of the perimeter. There are many cattles in the kampung consists of cow, chicken and goat. So, their solid waste is adequate to be recycled as biomas $-\mathrm{CH} 4$ fuel for daily activities. The calculation of biogass volume in kampung Sruni is described in the table below:

Table 7. Biogass potential energy in kampung Sruni

\begin{tabular}{lcccc}
\hline Resources & $\begin{array}{l}\text { Wet dirt } \\
\text { (kg/day) }\end{array}$ & $\begin{array}{l}\text { Biogas potential } \\
\text { (litre/day) }\end{array}$ & Total solid (\%) & $\begin{array}{l}\text { Volatil solid } \\
(\% T S)\end{array}$ \\
\hline Human & 129.5 & 20 & 0.200 & 518 \\
Cow & 200.0 & 280 & 0.200 & 11,200 \\
Chicken & 15.0 & 0.51 & 0.480 & 3,672 \\
Goat & 32.5 & 260 & 0.059 & 489,550 \\
\hline \multicolumn{7}{r}{} \\
\hline
\end{tabular}

Based on the calculation in table 7 , there is potential energy called biogas energy comes from the solid waste of inhabitants and the cattle at least $11,702.222 \%$ TS.

\subsection{Energy and Electricity}

The other alternative energy is a water energy comes from the potential strong energy of the Semanggung river that also has several springs in the surrounding it. The calculation of the energy in the Semanggung river is presented in the table and figure below:

Table 8. Average debit of the Semanggung river

\begin{tabular}{cccccc}
\hline TRIAL & Point A & Point B & Point C & Point D & Average \\
\hline 1 & 1,0 & 1.0 & 1,5 & 1,0 & 1,125 \\
2 & 0,9 & 1.0 & 1,5 & 1,0 & 1,100 \\
3 & 0,9 & 1,5 & 1,5 & 1,0 & 1,225 \\
\hline \multicolumn{7}{c}{ Average Debit (litre/second) } & & 1,150 \\
\hline
\end{tabular}

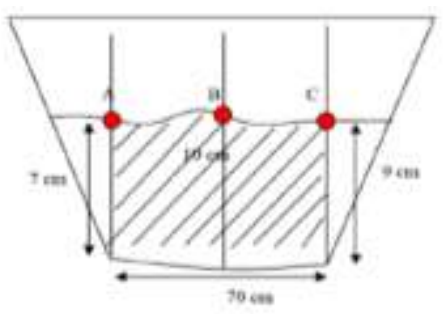

Figure 3. Cross section of potential energy measurement

Cross Sectional Area $=0,087 \times 0,7$ 


$$
\begin{aligned}
& =0,061 \mathrm{~m} 2 \\
Q & =0,061 \times 1,150 \\
& =0,0702 \mathrm{~m} 3 / \text { secon } \\
Q & =70.2 \text { liter/ secon }
\end{aligned}
$$

The equation to calculate the water energy is described below:

$P=Q \times H \times G \times E$

With $P$ is power generated in Watt, $Q$ is water debit in Litre/secon, $\mathrm{H}$ is different level in metre, $G$ is gravitation in $9.81 \mathrm{~m} /$ secon and $E$ is efficiency in $0.54-0.8$. and:

$P=Q \times H \times G \times E$

$=70,2 \times 15 \times 9,81 \times 0,6$

$=6197,958 \mathrm{Watt}$

It is assumed that the potential power in Semanggung river can be altered as an energy as much as 10 times with the MHTWT, so the kampung only needs 1 unit of turbine to accomodate the inhabitant electricity need because the total electricity consumption of households in the kampung is 58,500 Watt as descibed in table 9.

Table 9. Electricity Consumption in Kampung Sruni per day

\begin{tabular}{llll}
\hline $\mathbf{R T}^{*}$ & Households & $\begin{array}{l}\text { Electricity } \\
\text { consumption } \\
\text { (Watt) }\end{array}$ & $\begin{array}{l}\text { Total } \\
\text { (Watt) }\end{array}$ \\
\hline 05 & 22 & 450 & 9,900 \\
07 & 38 & 450 & 17,100 \\
08 & 31 & 450 & 13,950 \\
13 & 39 & 450 & 17,550 \\
\hline Total & 130 & & 58,500 \\
\hline
\end{tabular}

The map of the renewable energy distribution in kampung Sruni, Wonosobo is described in figure 4 . 


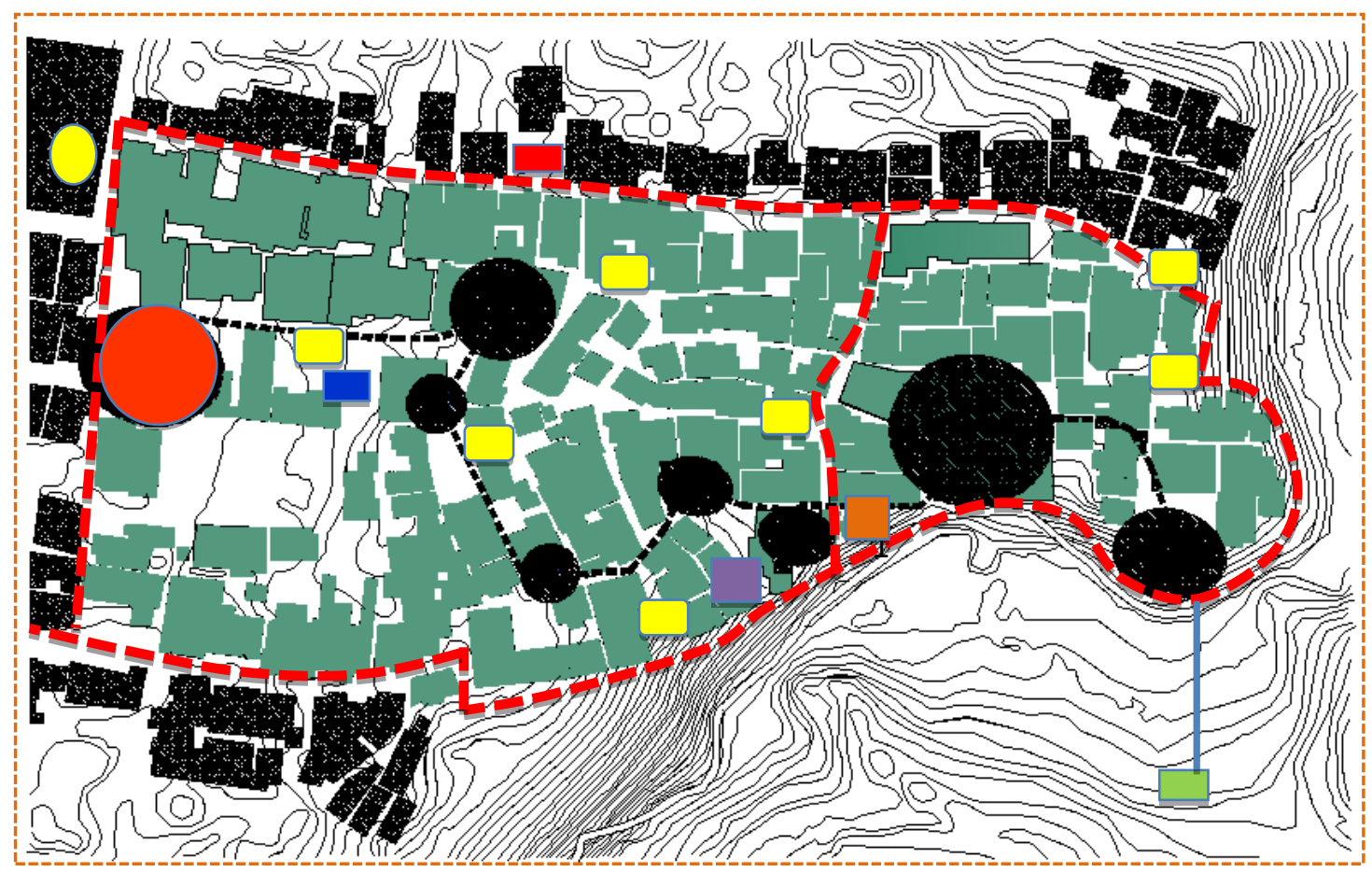

Note:

: Green open spaces

플 : Main street

- =- : Secondary pathway

: Communal Sanitation

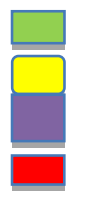

: Water wheel

: Rain water harvesting

: Biogas energy plant

: Waste Management

Plant

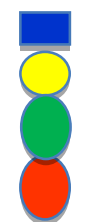

: Solar panel energy

: Dieng Creative Hub

: Urban Farming

: House of

Environment

Figure 4. Map of the renewable energy distribution in kampung Sruni

\section{Conclusion}

The principal concept for low carbon village in kampung Sruni is that the village should adjust the densification of housings and buildings within the perimeter. By adjusting the densification, the inhabitants will have more public green open spaces and will have a healthier and better environment. The renewable energy concept implemented in the kampung Sruni will support the kampung to be a low carbon village in the Wonosobo city as a model of the LCED program. The LCED program is issued by the Ministry of the public works and housing as effort to prevent and diminish the slum in Indonesian kampung and cities. The renewable energy concept is not only a greenery concept in the kampung Sruni, but also to reduce the energy dependency supplied by the PDAM and PLN as government bureau of the clean water and electricity supply. By reducing the dependency, the inhabitants can cut down the budget earned for the daily energy.

\section{Acknowledgments}

Authorsthank to the Ministry of public work and housing cooperated with the ADEME (French government) that held the International Design contest of re-thing the low carbon future in the April 2018. The content of this paper has been modified in different ways to give different opinion, and the third parties do not have intervention for those modifications.

\section{References}

Benger, S. N. (2014). Towards low carbon city planning in a medium sized low density City. Energy Procedia, 61, 838-841. https://doi.org/10.1016/j.egypro.2014.11.977 
Bong, C. P. C., Goh, R. K. Y., Lim, J. S., Ho, W. S., Lee, C. T., Hashim, H., ... Takeshi, F. (2017). Towards low carbon society in Iskandar Malaysia: Implementation and feasibility of community organic waste composting. Journal of Environmental Management, 203, 679-687. https://doi.org/10.1016/j.jenvman.2016.05.033

BPS, W. R. (2017a). Statistics Data of Wonosobo Regency 2017. Wonosobo: BPS Wonosobo.

BPS, W. R. (2017b). Wonosobo District Statistics 2017. Wonosobo.

BSN. (2005). SNI 03-7065-2005 Tata cara perencanaan sistem plambing, 1-17.

Cao, S., \& Li, C. (2011). The exploration of concepts and methods for low-carbon eco-city planning. Procedia Environmental Sciences, 5, 199-207.

Ge, J., Luo, X., \& Lu, J. (2017). Evaluation system and case study for carbon emission of villages in Yangtze River Delta region of China. Journal of Cleaner Production, 153, 220-229.

Jain, A. K. (2009). Low Carbon City: Policy, Planning and Practice. (A. K. Jain, Ed.) (1st Editio). New Delhi: Discovery Publishing House PVT.LTD.

Jenssen, T., König, A., \& Eltrop, L. (2014). Bioenergy villages in Germany: Bringing a low carbon energy supply for rural areas into practice. Renewable Energy, 61, 74-80.

Jiang, P., Chen, Y., Xu, B., Dong, W., \& Kennedy, E. (2013). Building low carbon communities in China: The role of individual's behaviour change and engagement. Energy Policy, 60, 611-620.

Mapes, J., \& Wolch, J. (2011). "Living green": The promise and pitfalls of new sustainable communities. Journal of Urban Design, 16(1), 105-126.

Middlemiss, L., \& Parrish, B. D. (2010). Building capacity for low-carbon communities: The role of grassroots initiatives. Energy Policy, 38(12), 7559-7566.

Moriarty, P., \& Wang, S. J. (2014). Low-carbon cities: Lifestyle changes are necessary. Energy Procedia, 61, 2289-2292. https://doi.org/10.1016/j.egypro.2014.12.439

Mulugetta, Y., \& Urban, F. (2010). Deliberating on low carbon development. Energy Policy, 38(12), 7546-7549.

Ruan, Y., Cao, J., Feng, F., \& Li, Z. (2017). The role of occupant behavior in low carbon oriented residential community planning: A case study in Qingdao. Energy and Buildings, 139, 385-394. https://doi.org/10.1016/j.enbuild.2017.01.049

Smith, C., Clayden, A., \& Dunnett, N. (2009). An exploration of the effect of housing unit density on aspects of residential landscape sustainability in England. Journal of Urban Design, 14(2), 163-187.

Su, M. R., Chen, B., Xing, T., Chen, C., \& Yang, Z. F. (2012). Development of low-carbon city in China: Where will it go? Procedia Environmental Sciences, 13(2011), 1143-1148.

Tan, S., Yang, J., \& Yan, J. (2015). Development of the Low-carbon City Indicator (LCCI) Framework. Energy Procedia, 75(Lcci), 2516-2522.

Xie, Z., Gao, X., He, J., \& Feng, C. (2016). Evaluating rural low-carbon communities: A study of Guangdong Province, China. Energy and Buildings, 133, 777-789. 